\title{
Norwegian synes and tro and Their English Translations
}

\author{
Bohumila Mia Chocholousova Fagertun
}

\begin{abstract}
The paper explores the possibility of using translation corpora for disambiguating the semantic content with some basic implications for second language acquisition. Norwegian verbs 'synes' and 'tro' are used as a baseline for the comparison. Their semantic content is systematically explored with help of the translation pairs found in the English-Norwegian Parallel Corpus. This article shows how translation corpora and contrastive analysis help to clarify similarities and differences in meaning and how it can clarify differences between the compared languages.

\section{Keywords}

corpus linguistics, contrastive analysis, comparative study, learner language, Norwegian, English, translation analysis, language acquisition, English-Norwegian Parallel Corpus, semantic analysis, pragmatic disambiguation
\end{abstract}




\section{Background}

This study was inspired by my experience with teaching Norwegian as a second language, as well as my own struggle to master the language. In both cases I came to a point where I had to semantically disambiguate the use of two Norwegian verbs synes and tro in areas where their meanings overlap into single form - 'be of opinion' or as most common translation dictionaries show, into a single English verb - think.

Both the Norwegian verbs have their own separate meanings too, which are further analyzed in section 5.1 of this study; the main focus of this paper, however, is directed to their congruent meaning. Like English, my native language: Czech completely lacks the reference that would help keeping their semantically overlapping content apart.

What is most natural for all native speakers of Norwegian, i.e. differentiate when to use synes and when to use tro in order to express their opinion, poses a great challenge for all other learners of Norwegian that lack the same semantic reference. The closest one can get in English (or Czech) is simply to use think for both.

The fact that there is only one verb in English to express this meaning for both synes and tro points us to the reality that the semantic difference is missing not only on the lexical level, but also on the level of our understanding. Observing the phenomena in practice resembles the 'Whorfian' hypothesis and the relativists' claim that language and thought are one (WHORF, 1956). For learners of Norwegian as a second language thus the semantic disambiguation must happen through pragmatic analysis of the context and mastering the usage rules.

Etymologically, if the development of think is traced back to the Old English period, we can see that there used to be two distinct words pencan and pyncan which later merged into one. And so did their meanings, which can explain the "semantic fuzziness" presentday think represents (PERSSON, 1993). A similar development can be found in Czech and in other Slavonic languages.

Norwegian, as well as most other Germanic languages, has kept both ancestry words and their meanings separate. In Old Norse sýnast (seem) and trúa (trust) are in presentday Norwegian represented by two distinct stance verbs synes and tro respectively. PERSSON (1993:9) states that this was common Germanic development for which we find evidence in other cognate verbs, such as dünken and denken in German. Disambiguating the meaning from the diachronic perspective can enhance our understanding of the semantic content, however it gives little practical outcome when it comes to using the verbs correctly in every day context.

In order to solve this puzzle, some fundamental questions arise. What patterns and tendencies can be found in the translation materials and how do they illuminate this problem? Can translation somehow affect our semantic understanding and help disambiguation? Can it have any didactic implications? 


\section{Introduction}

Both English and Norwegian have a range of means of expressing attitude or stance. Among these are verbs, adverbs, nouns and all kinds of lexical bundles used to express personal opinions.

In this analysis, however, I shall concentrate on some of the verbal expressions. As the main focus of this paper is on the Norwegian verbs synes and tro, I would like to examine (i) to what extent the two Norwegian verbs correspond with the English verb think; and (ii) what other correspondences can be found in the Norwegian-English and EnglishNorwegian translations. Further, I will concentrate on the semantic and pragmatic analysis of these two verbs in the context with help of the translation material.

In this respect, my project could be seen as supplementary to the one carried out by Karin Aijmer (AIJMER, 2002), who examined the correspondences of think in Swedish, German and Dutch. Similar research has also been carried out by Anne-Marie SimonVandenbergen (SIMON-VANDENBERGEN, 2002), who has compared English think to its Dutch translations.

The aim is to find some general patterns or tendencies found in the translations, define strategies used in translation for distinguishing between synes and tro with regard to their semantic content, and compare the results found in my material with Aijmer's conclusions concerning the fact that "I think is the general translation of both [Swedish] jag tror and jag tycker" (AIJMER, 2002: 288).

\section{Material and method}

The analyzed material is gathered from the English-Norwegian Parallel Corpus. The English-Norwegian Parallel Corpus (ENPC) is a computer corpus designed for contrastive analysis and translation studies. It was compiled at the University of Oslo and later became part of the Oslo Multilingual Corpus (OMC).

ENPC consists of original texts and their translations (English to Norwegian and Norwegian to English) and includes both fiction and non-fiction. The samples are limited to text extracts of 10,000-15,000 words. The fiction part of the corpus contains 30 original text extracts in each direction, whereas the non-fiction part contains 20 in each direction, amounting to 2.6 million running words in total. The texts are aligned at the sentence level and are encoded in accordance with the TEI conventions (JOHANSSON, EBELING, HOFLAND, 1996).

Translation pairs analyzed in this study are taken from all texts compiled in the ENPC. Computed results were checked and sorted out manually. Data not relevant for the analysis, e.g. false matches where no correspondence has been found, are excluded from the material.

Starting-points of my analysis are the Norwegian stance verbs synes and tro and their English translations. To contrast the two languages, both unidirectional and bidirectional translations will be used. The overall frequency of occurrence of individual items will 
be compared in both languages to trace general tendencies in usage. Pragmatic analysis will be used to help illuminate what is happening when the translator has to make a distinction that is not possible or present in the target language. Some semantic qualities of the two Norwegian stance verbs synes and tro will be discussed.

\section{Findings and discussion}

\subsection{Frequencies of occurrence}

According to the results found in the Longman Spoken and Written English Corpus (LSWE), think occupies the fifth position as regards the total frequency of occurrence of all English verbs (BIBER et al, 1999: 373).

If we look at the results from the ENPC, both Norwegian verbs synes and tro have a much lower frequency of occurrence as compared to think. To get a complete picture, however, we need to take into consideration other verbs expressing stance in Norwegian.

Since the most frequent counterpart of English think in Norwegian translations is the verb tenke, it has been included in the quantitative review for comparison. Cases where think, synes, tro and tenke occur in fictional and non-fictional texts are kept apart.

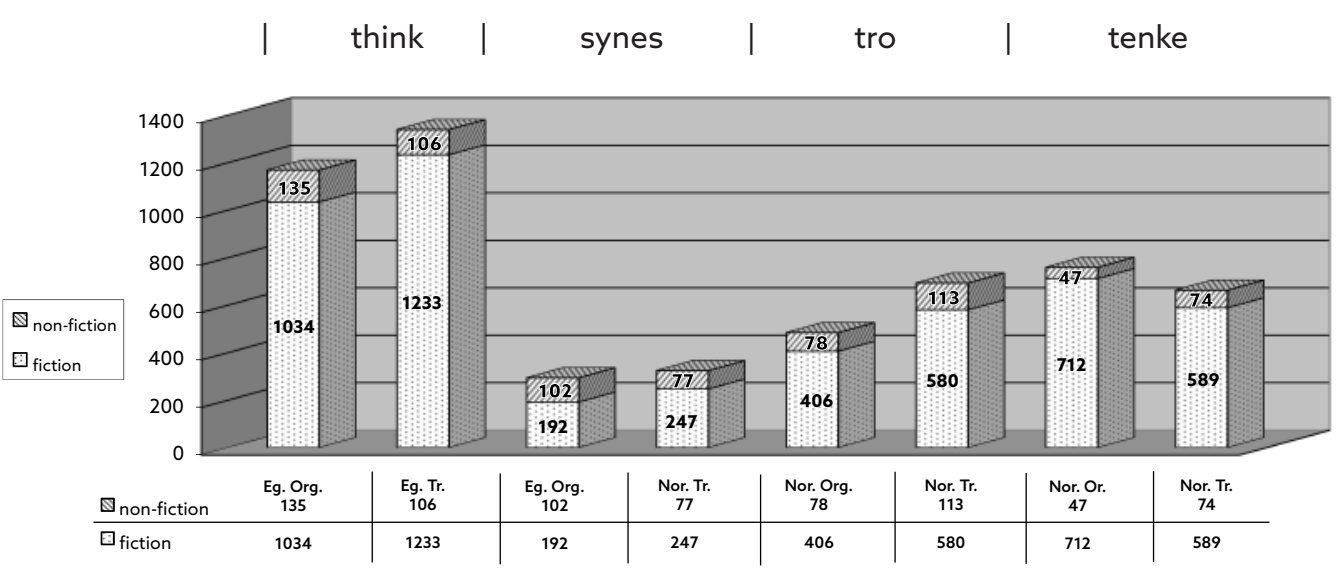

Figure 1: Total occurrences of think, synes, tro and tenke in the ENPC

Figure one shows that the total occurrence of think greatly outnumbers other verbs of stance in Norwegian. This clearly demonstrates the wide semantic area think covers. It is evident, however, that there is a significant increase in usage of think in translated texts.

Neither synes nor tro occur as frequently as think. The occurrence of tro, however, is twice as frequent as the occurrence of synes. If both Norwegian verbs are added together, we get a number of occurrences close to think. 
Analyzing the results closely, it is obvious that, as in the case of think, the frequency of synes and tro increases in translated material. The frequency of translations of tenke, on the contrary, shows a clear tendency to decline. As tenke is not included in this discussion, and still represents an important counterpart to think, it is worth further examining in order to get detailed analysis of all stance verbs in Norwegian.

The fact that the non-fictional part of the corpus is significantly lower is reflected by the results. Nevertheless, most verbs of stance obviously tend to be proportionally less frequent in the non-fictional part than the fictional part. This trend can be explained with regard to the register of non-fictional texts, which have a tendency towards depersonalization and 'objective' presentation of reality.

What is worth mentioning is that in the case of think and synes there is an opposite tendency in fictional and non-fictional texts with regard to their translations. The usual pattern is that the occurrence of universal stance verbs increases in translations, which was the case for tro in both the fictional and non-fictional parts. In case of synes and think the fictional results increased in translations, whereas the non-fictional results decreased. In further investigation it would be interesting to look closer into this pattern. For the purposes of this paper, this contradiction will be disregarded in the further discussion and both fictional and non-fictional parts will be analyzed together.

\subsection{Translation equivalents}

Let me investigate to what extent synes and tro correspond with, and to what extend they differ from think in the translations.

First, if we look into the results of the corpus study, we can immediately see that the distinction between synes and tro is by no means clear-cut. Both verbs can be translated by think, which shows that in English their semantic content partly overlaps. On the other hand, different lexical translation equivalents show that there are semantic areas where both verbs are kept separate in English, and are expressed by different English verbs.

For detailed overview see Table 1 below. Data in brackets in the table represent the occurrences of the verb with first person singular pronoun, e.g. 119 (27) means that 27 out of 119 occurrences of the verb appeared in first person singular. This distinction is made in order to draw direct comparison between the results found in ENPC and the results from Aijmer's study of Swedish stance verbs. Her conclusion is that I think is the prototypical translation equivalent for both Swedish stance verbs jag tror and jag tycker, which are the counterparts to the Norwegian stance verbs tro and synes (AIJMER, 1998: 289). 
Table 1: English translation correspondences with Norwegian verbs synes and tro

\begin{tabular}{|l|c|c|}
\hline & synes & tro \\
\hline think & $119(27)$ & $259(111)$ \\
\hline believe & $2(-)$ & $130(20)$ \\
\hline seem & $70(1)$ & $3(-)$ \\
\hline feel & $29(8)$ & $2(2)$ \\
\hline find & $24(1)$ & - \\
\hline imagine & $2(1)$ & $6(-)$ \\
\hline suppose & - & $10(8)$ \\
\hline guess & - & $7(1)$ \\
\hline expect & - & $7(2)$ \\
\hline to be sure & - & $4(3)$ \\
\hline realize & - & $3(-)$ \\
\hline wonder & - & $3(-)$ \\
\hline seem to think & 1 & - \\
\hline other & 14 & 28 \\
\hline$\varnothing$ & 33 & 21 \\
\hline TOTAL & 294 & 483 \\
\hline
\end{tabular}

Looking closely into the results, we can say that think is the most common translation for both synes and tro, with the latter being more frequent. Other common translations are seem and feel for synes and believe for tro. These English verbs clearly reflect areas in which synes and tro semantically differ. There is a general trend in translations to prefer the most semantically open equivalents. Along this line, the English verb think is used in the greatest number of cases in the translations of both synes and tro in order to express personal opinion. As Aijmer points out "If lexical item is polysemous, its functions are not clearly compartmentalized and ambiguity (or vagueness) cannot be avoided" (AIJMER, 1998: 282). The semantic content of think is markedly open and vague in most of the analyzed translation pairs. Other English stance verbs were quite rare in the material.

Interestingly, there were almost no cases in the English translations where a non-verbal phrase was used instead of a verb or verb phrase in the Norwegian original (except for one case where synes was translated as fine with me).

\section{(1) Jeg syns det er greit. (GN1) ${ }^{1}$}

Fine with me. (GN1T)

This is contradictory to the results found for the English original texts. As the Norwegian translations show, there are several examples of occurrences of noun phrases and adverb phrases in the English originals which were rendered in Norwegian by the two stance verbs synes and tro, such as in my view (3)리 how about (2), as to (somebody). (2), how

1 All examples of Norwegian-English and English-Norwegian translations are taken from the ENPC

2 Figures in brackets in the text represent the total frequency of occurrence of the particular translation pair in the ENPC. 
is that (1), and many single cases with different adverbials, such as surely, undoubtedly, clearly or apparently.

(2) How about trying it out, buddy. (AT1)

Hva syns du om å prøve det, kompis? (AT1T)

English translators seem to avoid paraphrasing the Norwegian stance verbs by different syntactical constructions, and tend to prefer verbal expressions, which correspond syntactically to the structure of synes and tro. Although it is possible to use a noun phrase or adverb phrase instead of using a verb (very likely the most general one like think) English translators seem to disregard this possibility.

Another interesting discrepancy between the English originals and the English translations is the fact that the English originals have a wider variety of English verbs translated into Norwegian as synes and tro. In the English original texts, we find instances of the following verbs translated into Norwegian as tro: suppose (10), expect (7), guess (increase in frequency: +5 cases), reckon (5), assume (4), suspect (4) or doubt (3). This clearly shows that English translations are more limited as to their lexical variety, and that, as compared to the originals, fewer verbs are used for translations of the Norwegian verb tro.

(3) I suspect she won't come. (ST1)

Jeg tror ikke hun dukker opp. (ST1T)

In the case of synes, the difference is less marked, but nevertheless quite obvious. In the English originals, the number of cases where the English verb find was translated into Norwegian as synes was eighteen (18); in English translations, on the contrary, just six (6) cases were found. In addition to that, several new verbs appeared as sources in English originals, such as consider (3) or regard (2) to match the Norwegian synes. This is the same tendency as the one found in the case of tro. English translations of both synes and tro thus seem to be less varied in the range of verbs found as correspondences.

(4) I find it most interesting. (JSM1)

Det synes jeg er interessant. (JSM1T)

These findings show that English translations of synes and tro are more limited as to paraphrasing the grammatical structures of the originals, and that the variety of verbs used in English translations is much lower compared to the variety of verbs found in English originals and congruently translated as synes or tro. The corpus findings show that the most general verb think is clearly preferred in translations.

To conclude, both synes and tro are commonly translated as think in English, which agrees with the findings of Karin Aijmer's investigation of think in the first person sin- 
gular and its Swedish translations (AIJMER, 2002). It is most natural for the translators, however, to use the closest equivalents which would be appropriate or acceptable in the target language. This explains why the most general term think is commonly used for translations of both synes and tro and why the frequency of occurrence of think increases in translations.

\section{Semantic Analysis}

\subsection{Semantic analysis of Norwegian-English translations}

Let me now concentrate more closely on the semantic environment of synes and tro with relation to their English translations. Both Norwegian verbs synes and tro are polysemous. I will first mention areas where both verbs have distinct meanings and do not semantically overlap. The main focus, however, is given to the examples where synes and tro express personal opinion and where English has no similar means how to reflect their semantic division on the lexical level. It will be interesting to see how this lexical distinction, which is not present in the target language, is reflected in the translations.

Looking at synes, we can distinguish between three main semantic areas where this verb is used. First, it is the area of 'coming to view', which can also be used metaphorically, and which is in the English translations mostly rendered by seem $(46)^{3}$, appear (7), see (3) or show (2). Second, it is the meaning 'be of opinion', which corresponds most often to think (119), feel (29), find (24) and seem (24). There is a subjective value to the opinion that can be expressed by synes, as it is apparent from the verbs used in the translations. Last, but not least, we find the Norwegian phrase 'synes synd' that corresponds to the English verbs, such as 'pity' (4).

(5) Jeg syns jeg ser inn i hele hans liv. (MS1)

I feel I am looking right into his whole life. (MS1T)

In the case of tro, two main meanings can be distinguished. Firstly, 'to have faith' which is commonly translated as believe (130) and occasionally by other verbs, such as trust (2). And secondly, 'be of opinion', which semantically overlaps with synes, and most often corresponds to the same English verb think (259); other verbs are used rather rarely in this sense and do not show any consistent trend.

3 The occurrence of synes in this semantic category is considerably higher in the non-fictional texts, both in originals and translations. The proportion of occurrence in fictional and non-fictional parts in Norwegion original text is $(7)$ to $(39)^{*}$. This is related to the difference in register and to the topics of the non-fictional texts. The style in non-fiction is often academic and depersonalised; it presents an objective description of reality often based on outside observations, which are very commonly referred to by means of verb + infinitive clause constructions: synes $a$ in Norwegian and seem to in English translations.

* Numbers in brackets represent the frequency of occurrence in the ENPC. 
(6) Hun tror på det hun sier. (EG1)

She believes in what she says. (EG1T)

In most cases, as it is apparent from the corpus findings, think is the most common translation counterpart for both synes and tro where they appear in their congruent meanings - 'be of opinion'. Tro is more objective and neutral in meaning as compared to synes. This means that think as the most general term sufficiently covers most cases where tro expresses opinion. This might be one of the reasons why English translators do not feel the need to use more varied lexical correspondence of tro, although it would be possible as we see in the English originals.

In the case of synes, the results found in translations indicate that the semantic match between synes and think is less congruent. English translations fill these semantic gaps by using different verbs. Apart from think, other lexical means are often applied to cover the epistemic meaning of expressing opinion that synes has. Most often the following two verbs can be found: seem (34) and feel (29), which highlight the subjective meaning of synes. This might indicate that think cannot in all cases cover the subjective semantic content of synes in communicating personal opinions.

To sum up, typical English translations of the Norwegian verb tro are believe and think; synes is, apart from think, also translated as seem or feel. In the area where synes and tro express opinion their semantic contents partially overlap. The general tendency, however, is pretty transparent. Verb tro expresses stance that is based on external evidence, whereas synes expresses subjective opinion.

In the corpus data one often looks for counterexamples that can verify or disprove those general tendencies. There were few cases where the translations deviated from this general pattern, such as when the former verb was translated by equivalents typical of the latter one and vice versa. It is important to know, however, that these cases are exceptional in the material and occurred in special semantic contexts.

There were two cases where synes was translated as believe (2), and three cases tro was translated as seem (3). We can investigate how do these unusual translation equivalents reflect the semantic relationship between synes and tro in Norwegian.

(7) Dessuten har jeg aldri synes det var sant at nordmenn er for kalde, for reserverte, for vanskelig å bli kjent med eller uvennlige. (ABJH1)

Second, because I've never really believed it was true that Norwegians were too cold, too reserved, too hard to get to know, or unfriendly. (ABHJ1T)

To interpret the level of subjectivity here we need the context. Starting from synes, the translator chose the verb believe for expressing personal attitude based on the individual perception of reality, rather than some external evidence. This subjective aspect of reality which believe expresses in Example 7 is not the most typical example of its use, but it is in line with the semantic content synes carries out in expressing the interior epistemic reality. 
In cases where tro was translated as seem, it was somehow important for the translator to highlight the fact that the speaker's perception of reality was based on the outside evidence, even if it was highly subjective at the same time:

(8) Jeg tror de hadde mye moro av å diskutere bøker de lånte på biblioteket vårt. (EG1)

They seemed to love discussing the books they got out of the library. We have a library here, you know. (EG1T)

Such cases where tro expressed personal opinions combining both objective facts and their subjective evaluation were reflected by seem in English translations. In Example 8 the translator changes the subject and thus shifts the perspective from I think they, as it is the case in the Norwegian original, into they seemed to in the English translation. The shift of sentence subject shifts the perspective of the whole sentence and enables to shift the perspective from the exterior to the interior. This shift is also reflected by the verbs. Synes focuses on expressing external evidence and objective opinion to it, whereas seem expresses internal subjective evaluation of that reality.

As the translations indicate, both stance verbs in Norwegian synes and tro are used to express opinion with varying degree of subjectivity. In areas where subjective and objective based opinions overlap, learners of Norwegian struggle and translators usually choose the most generic stance verb in English - think.

Think covers the whole spectrum of opinions ranging from highly subjective to highly objective, where synes and tro keep the distinction apart on the lexical level. As the corpus findings indicate, though, think is not a favored stance verb in cases where speakers express a highly subjective stance, such as Examples 7 and 8.

\subsection{Semantic analysis of English-Norwegian translations}

English translations do not illuminate the problem a foreign speaker has if he or she is to make a choice between synes and tro in Norwegian. English translators may simply use think to render both synes and tro when they express opinion. Therefore it is necessary to start with think in the English original and trace the potential semantic differences between synes and tro in the Norwegian translations in order to help learners to disambiguate the semantic content of the two verbs.

In the translated Norwegian texts, different sets of contextual clues defining synes and tro will be analyzed and systematically sorted out to reflect the main semantic features of both verbs. Additionally, we will examine how the context determines the choice between the two Norwegian verbs, and investigate to what extent semantic analysis based on translations illuminates the unclear semantic difference between synes and tro. 
The translation of think into Norwegian as tro is second highest in frequency after tenke (see Chart 1). Looking closely at the results where think was translated as tro, we find two main semantic features of the verb connected to conveying opinion.

The first typical semantic domain of tro used in translations of think is found when the speaker bases his/her opinion on outside evidence and if he/she is not the authority behind the opinion. Then the meaning of tro implies that the person is to some extent uncertain with regard to the comments he/she makes. In these cases the opinion shall be objectively verifiable. This is partly congruent with what Simon-Vandenbergen calls 'probability-based opinion' (SIMON-VANDENBERGEN, 2002: 304). To this category of meaning would belong similar sentences:

(9) The gun was among a jumble of textbooks, dog-eared exercise books, crumpled paper, and a pair of football socks, and for a single frightening moment Martin thought it was real. (RR1)

Revolveren lå blant et virvar av skolebøker, kladdhefter med eselører, sammenkrøllet papir og et par fotball sokker, en kort stund trudde Martin at den var ekte. (RR1T)

These expressions typically reveal some degree of '(un)certainty in opinion' and can often be either verified or disproved by reality. Syntactically, both verbs tro and think occur in combination with that-complement clauses or infinitive clauses.

Tro is often used to refer to generic opinions or to opinions of others. In this case it has reference to facts commonly shared within the society and the personal meaning it expresses is not subjective in the true sense.

(10) Delauny's argument is almost too precious to disturb with reputation, but it's probably worth mentioning that the paradigm case of a "higher" group with larger males - the mammals - is shakier than most people think. (SJG1)

Delaunays påstander er så kostelige at det nesten er synd å gjendrive dem, men det må være på sin plass å nevne at selve mønstereksempelet på en gruppe "høyerestående" dyr med størst hanner - pattedyrene - er svakere fundert enn folk flest tror. (SJG1T)

Similar examples were slightly more frequent in the non-fictional part of the corpus. On the lexical level, think in this meaning often collocates with first person plural, third person singular, plural pronouns, as well as depersonalized agents in passive constructions. This makes it possible for the speaker to distance himself/herself from the message that is being uttered. Syntactically, verbs in English originals tend to occur in passive forms, in such sentences Norwegian translations prefer active voice and a subject with generic reference. Such generic subjects in Norwegian are e.g. man, folk, noen or en as in the following example: 
(11) An estimated 5,000 boys and 3,000 girls work as prostitutes in Paris, and it is thought there may be as many as 300,000 boy prostitutes in the United States. (LTLT1)

Beregninger viser at 5000 smågutter og 3000 småjenter arbeider som prostituerte i Paris, og man tror at det kan finnes opptil 300000 gutteprostituerte i USA. (LTLT1T)

Another semantic domain where tro is used in Norwegian translations of think are examples where speakers express 'personal opinions'. These are used mainly in objective situations and in cases when some mental processing is involved, as can be seen in the following examples:

(12) I worked out the financial terms as exactly as I could, and I don't think I could bring any of the figures down. (RDA1)

Jeg beregnet de pengemessige betingelsene så nøye jeg kunne, og tror ikke jeg vil være i stand til å redusere noen av summene. (RDA1T)

As this example shows, the evaluation or opinion is based on mental processing of reality; and some evidence of thought is either explicitly or implicitly present in the semantic context. If used in questions, such cases require some train of thought for the answer. As compared to 'probability based opinion' where generic subjects are often involved (see example 10/11), in the context of 'personal opinion' tro collocates more frequently with a first person singular pronoun. Another example is given for illustration:

(13) I think that this is one of the most crucial verses in Jeremiah. (HB1)

Jeg tror dette er et av de viktigste versene hos Jeremia. (HB1T)

To continue with synes, we will start the discussion where its semantic content partly overlaps with the other Norwegian verb tro. It is the area where synes also expresses 'personal opinion'. Unlike tro, synes is purely subjective in expressing opinion. Personal opinions introduced with synes are therefore very often evaluative and based on personal experience of the speakers, i.e. things they have seen, tried or experienced in their lives. Moreover, these personal opinions are unverifiable in relation to the external reality and the "speaker is the sole authority for what is claimed" (AIJMER, 2002: 284). Following two examples illustrate the trend:

(14) He thought they were both finer and unhealthier. (AT1)

Han syntes de så både penere og sykeligere ut. (AT1T) 
(15) "The Bertolucci - an Italian film - it's very good," he said, delicately avoiding the implications of the natural prefix, "We thought..." (NG1)

Bertolucci-filmen - italiensk - den er meget god, sa han og unngikk taktfullt å legge til "synes vi". (NG1T)

Simon-Vandenbergen differentiates between two sub-categories in the semantic category of 'personal opinion'; these are 'pure opinion' and 'subjective evaluation' (SIMON-VANDENBERGEN, 2002: 302). Example (14) represents 'pure opinion' which is objectively unverifiable, whereas example (15) can be defined as 'subjective evaluation' derived from personal experience. In both cases, however, the statements are subjective and are based on feelings rather than mental processing of reality. This is the semantic area where synes clearly differs from tro, and for the purpose of this study both these subcategories will be treated as one semantic domain, 'personal opinion' (see Table 2 for detailed overview).

With regard to the fact that synes introduces opinions which are based on previous experience, it tends to collocate with verbs of perception, such as the English see, taste or hear.

(16) And now, for the first time, he thought that he could smell the North Sea [...]. (PDJ3)

Nå fikk han også den første eimen av Nordsjøen i nesen, syntes han. (PDJ3T)

Lastly, as the experience which synes introduces precedes the opinion, synes refers only to the present and past states of mind. As a result, it never collocates with expressions referring to future, and it can only express current opinions.

(17) You'll think this strange, Andrew, but one day I'd like to go to where my father died, though not alone. (AHT1)

En dag ønsker jeg å gå dit min far døde, men ikke alene. Synes du det virker rart? (AHT1T)

Even if think in the English original is combined with future tense, the message synes conveys is limited to the presence. In fact, there was only one such example found in the ENPC:

(18) "I think in the morning we ought to tell Daddy what she's doing." (TH1)

„Jeg synes vi skulle fortelle pappa om det i morgen.“ (TH1T)

For drawing any didactic conclusions, how do the two Norwegian verbs synes and tro differ in expressing opinion? For tro we have identified two distinct semantic areas 'probability based 
opinion', which can be (dis)approved by external reality, and 'personal opinion', which is based on the speaker's mental processing, generally shared opinion or a train of thought.

For synes we have identified only one semantic area 'personal opinion', which can be either a purely subjective judgment independent of reality, or an evaluation based on previous experience. Although both synes and tro share the same semantic domain 'personal opinion', their distinct meanings are kept apart in Norwegian as shown in Table 2.

Table 2: Different areas of use of synes and tro as reflected by the semantic context

\begin{tabular}{|l|l|l|}
\hline Semantic area: & synes & tro \\
\hline 'personal opinion' & $\begin{array}{l}\text { - subjective non-verifiable evaluation } \\
\text { (e.g. example 14) } \\
\text { - opinion based on previous experi- } \\
\text { ence } \\
\text { (e.g. examples 15, 16 and 17) }\end{array}$ & $\begin{array}{l}\text { - opinion based on mental process- } \\
\text { ing } \\
\text { (e.g. examples 12 and 13) }\end{array}$ \\
\hline $\begin{array}{l}\text { 'probability based } \\
\text { opinion' }\end{array}$ & - & $\begin{array}{l}\text { - opinion based on objective external } \\
\text { evidence (e.g. examples 9, 10 and 11) }\end{array}$ \\
\hline
\end{tabular}

Table 2 shows where synes and tro differ and where they partly overlap when expressing opinion. It is necessary to distinguish between evaluations based on subjective experience where synes is used, and contexts where speakers refer to available objective evidence or express certain degree of uncertainty where tro is the correct translation. This basic scheme could navigate all learners of Norwegian as a second language to use both verbs correctly, and sometimes is already present in the textbooks (cf. Mac DONALD, 2009).

Nevertheless, semantic boundaries between these two verbs are not clear-cut. As the corpus results indicate, there are fuzzy zones where one needs to interpret the pragmatic context in order to choose the right lexical item. And not only that, there are examples where both verbs can be used, but each produces different meaning, such as in the following example:

(19) For quite a long way, I think. (RD1)

Ganske langt, tror jeg. (RD1T)

Using tro in the translation indicates that the translator interprets the semantic meaning of think inside this pragmatic context as objectively verifiable. One could, however, use synes instead and the sentence would be perfectly grammatical.

(*19)Ganske langt, synes jeg. (*own translation)

The meaning, though, would be different. Synes would point out the subjective evaluation of the speaker, who would be sure of that statement, based on his/her feeling or previous experience. This claim would not be objectively verifiable, but rather subjectively (dis)approvable (cf. AIJMER, 1998). 
What didactic implications does this have? Translation corpus proves to be a very useful tool for disambiguating meaning in areas where languages divide semantic content differently. It provides evidence for the semantic reference that is missing in the target language. Contrastive study of the translation pairs enlightens areas where one language makes a lexical distinction (i.e. Norwegian synes and tror) and the other one does not (i.e. English think). Practical conclusions can be drawn from the analyzed data that help define rules for the correct usage of both verbs in the appropriate context.

To investigate this problem more thoroughly, it would be necessary to concentrate further on cases where both synes and tro are mutually interchangeable (example 19), and where the choice between them influences the semantic and pragmatic content of the whole sentence (examples 7 and 8). Such corpus investigation can be worthy even in small-scale projects where students define their own usage rules.

\section{Conclusion}

The corpus findings have enabled us to contrast the English stance verb think with Norwegian verbs synes and tro. Whereas the semantic distinction between evidentiality based and subjective opinion is mainly contextual in English, Norwegian distinguishes between these two meanings on the lexical level, i.e. by two distinct verbs, synes and tro.

Think as the stance verb with widest semantic content has the highest frequency of occurrence in the ENPC. Interestingly, the semantic vagueness of think does not seem to be a problem in English. The interpretation of meaning that think carries largely depends on contextual and other pragmatic clues. However, such interpretation only becomes transparent in the context of translation where such interpretation becomes evident in the lexical choice made in the target language.

In English as such there seems to be no need for semantic disambiguation between the opinions think introduces. As Hawkins puts it: "Languages can vary in the extent to which numerous semantic distinctions are explicitly drawn in surface morphology. Not to draw these distinctions in surface does not render them inexpressible and does not make the language in any sense impoverished - it simply means that their expression is carried by fewer linguistic forms, each with broader semantic coverage (i.e. more ambiguity and vagueness)." (HAWKINS 1986: 28).

Think represents such form. The total occurrence of think is relatively more frequent in translated texts as compared to original texts, which indicates that the most general expressions are favored in translations. As the most semantically open or vague stance verb, think is preferred to more specific verbs or other syntactic devices found in English originals. English translators may thus be encouraged to use more invention and enrich their translations with more specific verbs and other lexical forms when it comes to rendering the opinion synes and tro can convey in Norwegian.

The fact that think is the most common English translation of both the Norwegian stance verbs synes and tro confirms Aijmer's results (AIJMER, 2002). If we take a look in the opposite direction, i.e. in the Norwegian translations, it is the semantic context 
around think that determines whether synes or tro will be used to reflect the meaning of think.

Pragmatic analysis was used to define semantic areas where the two verbs synes and tro typically occur. Translation pairs helped to disambiguate the semantic content of the two verbs. Patterns found in translation pairs were used to define semantic areas where each verb typically occurs. Those semantic areas might be used as guidelines for learners of Norwegian as a second language and enhance correct use of synes and tro in the appropriate context.

First, there is the category of 'probability based opinion' where the speaker expresses some level of (un)certainty, refers to external evidence, and is not the authority behind the statement, only tro can be used; synes does not occur in this context.

Second, if the speaker expresses 'personal opinion' both stance verbs might be used in different contexts. When the personal opinions are based on some previous experience, or express some subjective evaluation, synes rather than tro is to be used.

Last but not least, if the personal opinions require some mental processing of the reality, and some train of thought is involved; the more objective of the two verbs - tro is the proper choice.

I have used this opportunity to demonstrate what translation corpora has to offer, and how it can be used to enhance second language acquisition. Namely to help us understand areas where languages divide their semantic content differently. Translation pairs found in the corpus disambiguate the meaning and illuminate areas where one language makes a lexical distinction which is not made in the other one. In these areas learners of the second langue struggle, as neither the lexical nor the semantic distinction is available in their source language. In places where there is no reference point between language two and language one, the corpus might provide for the missing reference.

This article offers only a short presentation of the matter, and analyzes only two verbs which express opinion in Norwegian. To get a complete picture of the behavior of stance verbs in English and Norwegian, more stance verbs should be included in the study, namely 'tenke' and 'mene'. This would be a possible extension of the present study.

\section{References}

\subsection{Primary sources}

English-Norwegian Parallel Corpus (ENPC):

http://www.hf.uio.no/ilos/english/services/omc/enpc/

Oslo Multilingual Corpus (OMC):

https://www.hf.uio.no/ilos/english/services/omc/ 


\subsection{Secondary sources}

AIJMER, Karin (1998): Epistemic Predicates in Contrast I. In Stig Johansson, Signe Oksefjell (eds.). Corpora in Cross-linguistic Research: Theory, Method and Case Studies. NY: Rodopi. 276-294.

AIJMER, Karin (2002): Epistemic Predicates in Contrast II. In Hilde Hasselgård (eds). Information Structure in a Cross-Linguistic Perspective. NY: Rodopi 24: 277-295

BIBER, Douglas et al. (1990): Longman Grammar of Spoken and Written English, London: Longman.

HAWKINS, John A. (1996): A Comparative Typology of English and German: Unifying the Contrasts. London and Sidney: Groom Helm.

JAMES, Carl (1980): Contrastive Analysis. New York: Longman.

JOHANSSON, Stig (1998): “On computer corpora in contrastive linguistics.” In: COOPER, W. R. (ed.), Compare or Contrast? Current issues in cross-language research. Tampere Studies in English. University of Tampere. 269-289.

JOHANSSON, Stig, Jarle Ebeling, and Knut Hofland (1996): "Coding and aligning the EnglishNorwegian Parallel Corpus.” In: K. Aijmer, B. Altenberg, and M. Johansson (1996), Languages in Contrast. Lund: University press. 87-112.

MAC DONALD, Kirsti: Norsk grammatikk: Norsk som andrespråk. Oslo: Cappelen Damm.

PERSSON, Gunnar (1993): Think in Panachronic Perspective. Studia Neophilologica 65: 3-18

SIMON-VANDENBERGEN, Anne-Marie (2002): I think and its Dutch Equivalents in Parliamentary Debates. In Hilde Hasselgård (eds). Information Structure in a Cross-Linguistic Perspective, NY: Rodopi 24: 297-317

WHORF, Bebjamin Lee (1956): Language, Thoughts and Reality: Selected Writings of Benjamin Lee Whorf. Cambridge, MA. Mit Press

PhDr. Bohumila Mia Chocholousova Fagertun, M.A. / mia.fagertun@icloud.com Ústav germanistiky, nordistiky a nederlandistiky, Filozofická fakulta Masarykovy univerzity Arna Nováka 1, 60200 Brno, Česká republika 
